\title{
The Effect of Online Learning on Indonesian Students Learning Outcome of Tanjungpinang Senior High School in The 2020/2021 Academic Year
}

\author{
Legi Elfitra ${ }^{1}$, Ahada Wahyusari ${ }^{2}$, Indah Pujiastuti ${ }^{3}$, Wahyu Indrayatti ${ }^{4}$, Dian Lestari ${ }^{5}$ \\ $\left\{\right.$ legi_elfitra@umrah.ac.id ${ }^{1}$, ahadawahyusari@umrah.ac.id², indah.puji@umrah.ac.id ${ }^{3}$, \\ dianlestari.zh@gmail.com ${ }^{4}$ \}
}

Department of Indonesian Language and Literature Education, Faculty of Teacher Training and Education, Raja Ali Haji Maritime University, Senggarang, Tanjungpinang, Indonesia

\begin{abstract}
The purpose of this research is to determine the effect of online learning on the learning outcome of Indonesian high school students in Tanjungpinang City. This is a quantitative research carried out using the ex post facto method. Data were collected through questionnaires and documentation techniques. The data collected were analyzed through normality, linearity, and simple linear regression tests. The results obtained showed that $\mathrm{t}$-count is greater than $\mathrm{t}$-table $(2.447>1.664)$. Therefore, hypothesis Ha stated that online learning significantly influences Indonesian language learning outcomes for Tanjungpinang City High School students in the 2020/2021 academic year is accepted. In conclusion, $\mathrm{Ha}$ is accepted because the t-count is greater than the t-table, while Ho is rejected with the r-square value of 0.074 , which indicates that online learning on the Indonesian language is $7.4 \%$.
\end{abstract}

Keywords: Influence, Online Learning, Learning Outcomes

\section{Introduction}

Raja Ali Haji Maritime University (UMRAH) is committed to synergizing and collaborating with the Tanjungpinang City Government to improve the quality of human resources (HR). This is because qualified and highly competitive human resources realize quality development, specifically in the fields of science and technology. Cooperation is also carried out to explore the regional potentials of this maritime area, as stated in the MoU Number 1379/UN53.0/KS/2020 between UMRAH and the Tanjungpinang City Government.

As part of UMRAH, the Indonesian Language and Literature Education Study Program need to take on certain roles to achieve this goal. Furthermore, alumni must be prepared to become a resource for prospective Indonesian language teachers specializing in chemistry lessons based on maritime contexts. This indirectly improves the quality of students in Tanjungpinang, thereby making them familiar with the region's potentials. In the educational sector, information technology is focused on improving the quality of learning [1]. This led to the implementation of the online or e-learning program by some schools. The University of Illinois first introduced online learning with the development of electronic-based learning [2].

Based on interviews and observations, schools implemented online learning using Whatsapp, Google Classroom, and Google Meet. Everyone often used these selected media to convey information, even before the government implemented the online learning system. Besides, these media also have several features such as forming groups, sharing files and pictures, filling in the attendance list, making video calls, sending voice messages, etc, thereby enabling educators to send, give, and assess assignments online. The implementation of this 
type of learning aims to aid the students even in adverse conditions such as the Covid-19 pandemic. Learning activities are important and have become the main factor in achieving academic objectives, such as reading, writing, story-telling, asking questions, listening, and practicing.

Students are also faced with several online learning problems in Indonesia. First, it limits their ability because some cannot provide the needed communication tools such as cellphones, which causes them to often ignore Indonesian language lessons. This is also one of the reasons they do not participate in learning activities. Second, students feel bored because of the numerous hours needed to participate in online learning and the associated series of tasks that the teacher continuously gives. Third, they are less active in asking questions, and fourth, the lengthy tests make it difficult for them to capture the lessons, and they are sometimes lazy to read. However, when given assignments, the majority of the students fail to submit while others earn low scores due to their poor performance.

Formal education is continuously followed by measurement and assessment, as well as the teaching process and learning activities. This means by knowing the learning outcomes, it is easier to determine students' position that is smart, moderate, or slow. Therefore, education always needs to be improved in terms of quality and quantity [3]. Husman (2016) stated that "Learning outcomes are the abilities possessed by students after learning experiences." These are described as their competencies or abilities obtained after carrying out the learning activities as well as a measure to determine the extent they understood the provided material. In accordance with the preliminary research, it was reported that online learning at SMK Ketintang Surabaya significantly affects students' learning outcomes. This is because t-count $8.396>\mathrm{t}$ Table 1.99773 and the significance result was realized as $0.000<0.05$. Therefore, it was concluded that online learning has a positive and significant impact on the learning outcomes of class X students in the subject of office technology. In addition, learning is a process that involves a combination of 2 aspects, namely, which are aimed at students' abilities, and teaching which is oriented towards teachers' competence. Electronic learning is an English word derived from learning online. According to Susanto (2013), it is a combination of learning and teaching activities. Meanwhile, learning is a process that involves the interaction between students, educators, and educative resources in a conducive environment [4]. It is also defined as the act of changing students' behaviors by optimizing the environment as a source of stimulus study.

\section{Results and Discussion}

\subsection{Results of Online Learning Questionnaire for Tanjungpinang City High School Students for 2020/2021 Academic Year}

The research questionnaire is composed of 20 statements that were prepared based on an online learning grid, which has been tested for validity and reliability [5]. Siregar (2014), stated that the Likert scale is used to measure a person's attitudes, opinions, and perceptions on a particular object or phenomenon. It was in the assessment technique which was awarded a score of $1,2,3,4$, and 5 . A closed questionnaire in which each statement is awarded, a score was distributed and filled with positive and negative statements. However, assuming the positive statement is awarded scores of $5,4,3,2,1$, then the negative one becomes 1, 2, 3, 4, 5 . Information from the positive statement with a score of 5 is categorized as strongly agree. Furthermore, scores of 4, 3, 2, and 1 are in the agreed, neutral, disagree, and strongly disagree categories, respectively.

Based on the online learning questionnaire scores, detailed results were obtained. Approximately 70 and 50 students were awarded moderate scores of 67 and 73 . Furthermore, 
the highest and lowest scores were 89 and 50, which were obtained by 20 and 10 students, respectively. The purpose of distributing this questionnaire is to determine the extent of influence online learning has on students of the Indonesian language. Therefore, in accordance with the scores obtained, it was concluded that it impacts their learning outcomes.

\subsection{Learning Outcomes of Final Semester Grades for High School Students in Tanjungpinang City for the 2020/2021 Academic Year}

The indicator used to measure the learning outcome during the final semester exam held in Tanjungpinang High School for the 2020/2021 academic year is the field of knowledge. The final results were obtained in the form of documents and were described afterward. The average score of 63.70 was realized with the help of Microsoft Excel 2010.

\subsection{Normality Test}

The normality test is the first prerequisite carried out and used to analyze data processing using statistical tests. According to Siregar (2014), "Supposing the data is normally distributed, then a parametric statistical test is carried out, whereas assuming otherwise, then a nonparametric statistical test is performed." The normality test aims to determine whether the data obtained from the research is normally or abnormally distributed. It is carried out on parametric statistics, in accordance with the assumption that the data obtained is normally distributed, using the Kolmogorov-Smirnov test.

\subsection{Hypothesis Test}

\subsubsection{Simple Linear Regression Test}

Siregar (2014) stated that "one of the tools used to predict future demand based on previously acquired data, or to determine the effect of one independent variable on a dependent is linear regression." This aims to determine whether or not online learning affects students of the Indonesian language in Tanjungpinang High School during the 2020/2021 academic year, using SPSS version 22.

Based on the results shown in the coefficients table, it is evident that the t-count and significance values are 2.447 and 0.017 , respectively. Furthermore, in the model summary table, the r-square, an output guideline to determine the magnitude of the influence of online learning on the outcomes of Indonesian subjects, is 0.074 . This means that online learning affects $7.4 \%$ of Indonesian learning outcomes, while other variables influence the remaining $92.6 \%$. Subsequently, a regression line equation was obtained with the following formula.

$\mathrm{Y}=\mathrm{a}+\mathrm{bX}$

The explanation of the formula above is a constant number a, with numerous coefficients. The SPSS version 22 output was used to determine the value of a as 35.187 . This result is a constant, which means that when there is no online learning of Language $\mathrm{X}$, the consistent value outcomes is 35,187 . Furthermore, b depicts the number of regression coefficients, and the value obtained is 0.418 . This means that for every $1 \%$ rise in online learning rate orlahasale $\mathrm{X}$, the learning outcomes increase by 0.418 .

Based on the discussion above, the regression coefficient value obtained as $\mathrm{Y}=35.187$ $+0.418 \mathrm{X}$ is positive. It was reported that online learning orlahasale $\mathrm{X}$ has a positive effect on learning outcomes 1 Indonesian or 1 ahasa $1 \mathrm{e} \mathrm{Y}$. After the values of $\mathrm{a}$ and $\mathrm{b}$ are obtained, then the validity of the regression equation was determined with a significance analysis based on the ttest. 


\subsubsection{Significance Test}

A significant test was performed using the t-test, and it obtained a t-count of 2.447 , while the t- table with a significance level of 0.05 , at a value of 1.664 . Furthermore, assuming the t-count is equal to or greater than the t-table with a significance level of 0.05 , then the language, which has a significant effect and $\mathrm{Ha}$, is accepted. Conversely, assuming the t-count is smaller than the t-table, the language is insignificant, and Ho is accepted. The t-test was carried out to verify the proposed hypothesis, and afterward, conclusions were drawn by comparing the t-count with the t-table at a significance level of 0.05 or $5 \%$. Degrees of freedom $(\mathrm{DK})=\mathrm{n}-2=77-2=75$, then $\mathrm{t}$-table $=1.664$, which are based on the guideline $\mathrm{dk} \mathrm{t}$-table. The hypotheses in this research are proposed as follows:

Ha: indicates a significant influence between online learning on outcomes 1Indonesian language for Tanjungpinang High School students for the 2020/2021 academic year. The hypothesis is accepted assuming t-arithmetic $>\mathrm{t}$-table at $\mathrm{DK}=\mathrm{n}-2$ and $\mathrm{p}=0.05$. The hypothesis is rejected when $\mathrm{t}$-count $<\mathrm{t}$-table at $\mathrm{DK}=\mathrm{n}-2$ and $\mathrm{p}=0.05$.

Ho: indicates an insignificant effect on online and on learning outcomes 1Indonesian language for Tanjungpinang High School students for the 2020/2021 academic year. The hypothesis is accepted assuming $\mathrm{t}$-count $<\mathrm{t}$-table at $\mathrm{DK}=\mathrm{n}-2$ and $\mathrm{p}=0.05$. The hypothesis is rejected supposing $\mathrm{t}$-count $>\mathrm{t}$-table at $\mathrm{DK}=\mathrm{n}-2$ and $\mathrm{p}=0.05$.

The test results show that $\mathrm{t}$-arithmetic is greater than $\mathrm{t}$-table $(2.447>1.664)$ Therefore, hypothesis Ha states that online learning has a significant influence on learning outcomes 1Indonesian language of Tanjungpinang High School students for the 2020/2021 academic year, is accepted. It was concluded that $\mathrm{Ha}$ is accepted because it fulfills the requirements of the proposed hypothesis, namely t-count is greater than t-table while Ho is rejected. This indicates that online learning has an effect on the Indonesian language learning outcomes of Tanjungpinang High School students for the 2020/2021 academic year. Based on the regression output, r-square is 0.074 , which shows that online learning on Indonesian language learning outcomes is $7.4 \%$.

\section{Conclusion}

The total research sample of 770 students involved in online learning at the Tanjungpinang City High School for the 2020/2021 academic year had an average score of 68.15. Meanwhile, the SMA Tanjungpinang City XI students' result for learning Indonesian had an average score of 63.70 and is categorized as sufficient. Therefore, the conclusion drawn from the formulated problem is that students understood the online learning system. This is proven by their answers to the questionnaires with a coefficient of $r$ of 0.074 . In terms of learning Indonesian, an average score of 63.70 was realized and categorized as sufficient. This indicates online learning positively influences Indonesian language learning outcomes with a coefficient of r-square $=0.074$ and a significance of $0.017<0.05$. This means that it affects Indonesian language learning outcomes for high school students in Tanjungpinang City. 


\section{References}

[1] Prasojo, et al. 2016. Educational Information Technology. Yogyakarta: Gava Media.

[2] Yuliani, et al. 2020. Online Learning for Education: Theory and Application. E-book: Our Foundation Writes.

[3] Husmah, et al. 2016. Learning \& Learning. Unfortunate: UMM Press.

[4] Suardi, Moh. 2018. Learning and Learning. Yogyakarta: CV Budi Utama.

[5] Siregar, Syofian. 2014. Parametric Statistics for Quantitative Research Supplemented with Manual Calculations and SPSS Applications Version 17. Jakarta: Bumi Aksara 